\title{
The Effect of Authentic Leadership on Intrinsic Motivation of Millennial Engineers Working in Information Technology (IT) Sector
}

\author{
Birgül AYDOĞDU ${ }^{\left(D_{a}\right.}$ Deniz PALALAR ALKAN ${ }^{\text {id }}$ \\ a Software Development Manager at ING, İstanbul, Turkey birguluzum@gmail.com \\ ${ }^{b}$ Yeditepe University, Faculty of Economy and Administrative Sciences, İstanbul, Turkey deniz.alkan@yeditepe.edu.tr
}

\begin{tabular}{ll}
\hline ARTICLE INFO & ABSTRACT \\
\hline Keywords: & $\begin{array}{l}\text { Purpose - This study focuses on millennial engineers working in IT sector in Turkey and aims to } \\
\text { investigate the effect of authentic leadership on their intrinsic motivation on the basis of self- } \\
\text { Authentic Leadership }\end{array}$ \\
$\begin{array}{l}\text { Intrinsic Motivation } \\
\text { Millennial Generation }\end{array}$ & $\begin{array}{l}\text { Design/Methodology/Approach - This study is a descriptive study exploring the relationship } \\
\text { between authentic leadership and intrinsic motivation of millennial engineers. Survey technique is } \\
\text { used and online survey is carried out with the engineers working for at least one year or more in IT } \\
\text { departments of different companies operating in finance, telecommunication and software } \\
\text { development sector in Turkey. The sample size is 196 and the sample includes both male and female } \\
\text { engineers at different ages belonging to millennial generation. } \\
\text { Revised 1 July 2019 }\end{array} \quad \begin{array}{l}\text { Findings - This study shows that there is a positive relation between authentic leadership and } \\
\text { intrinsic motivation of millennial engineers. This means that authentic leadership increases intrinsic } \\
\text { motivation of millennial engineers and millennial engineers working with authentic leaders show } \\
\text { more self-determined behaviors and involve more in activities that they are inherently satisfied by } \\
\text { doing. This result has important implications for the organizations that have millennial engineers. } \\
\text { Research Article } 2019\end{array}$ \\
$\begin{array}{l}\text { Research Limitations/Implications - More generalizable findings might be obtained if this study is } \\
\text { carried out by a larger number of participants working in IT departments of companies operating in } \\
\text { different sectors and if the data are collected within a longer time frame. } \\
\text { Practical Implications - This study includes managerial implications for organizations in } \\
\text { developing, training, recruiting leaders and in strategy making processes. } \\
\text { Originality/Value - There is a limited literature on the effect of authentic leadership on intrinsic } \\
\text { motivation of millennials. This thesis aims to fill this gap in the literature and the conclusions drawn } \\
\text { are intended to provide guidance to leaders and managers to better understand and motivate } \\
\text { millennial engineers in order to sustain the workforce in the long run. }\end{array}$ \\
\hline
\end{tabular}

\section{INTRODUCTION}

In today's world, technology changes rapidly and companies struggle to keep up with these changes and compete with their rivals. Therefore, they heavily invest on their Information Technology (IT) resources. The engineers working in IT departments are one of the most valuable resources of companies. In companies with strong human IT resources, (1) IT and business units communicate, plan, work more efficiently and effectively; (2) reliable and cost-effective applications are developed that meet business units' needs; (3) innovative products and features are introduced by successfully predicting the future trends; (4) the competitors are left behind (Bharadwaj, 2000). In order to hire the most talented engineers, companies carry out detailed selection processes and after the hiring process they go on with training, development, engagement and motivation processes. All these processes cost significant amount of time and money to companies and when there is a high turnover rate after a short period of time, then this cost gets much higher.

Sujansky et al. (2009) states that as millennials are joining the workforce, the companies are faced with the difficulty of understanding millennials and finding ways to motivate them in order to increase tenure. Millennials look for companies with leaders who inspire and challenge them. They want their leaders to provide them with the resources necessary to do their job and create opportunities that will help them

\section{Suggested Citation:}

Aydoğdu., B., Palalar Alkan, D. (2019). The Effect of Authentic Leadership on Intrinsic Motivation of Millennial Engineers Working in Information Technology (IT) Sector, Journal of Business Research-Turk, 11 (3), 1503-1517. 


\section{B. Aydoğdu - D. Palalar Alkan 11/3 (2019) 1503-1517}

develop their skills and talents. If these expectations are not met, then millennials have higher intention to leave the existing organization. Per-job tenure of many millennials ranges from 2 to 5 years and the turnover costs of millennials can range from 50 to 150 percent of their salary. Sujansky et al. (2009) further points out that "Unless companies find ways to attract millennials more effectively, the turnover problem will continue to cost companies dearly." (p. 4).

\section{BACKGROUND AND LITERATURE REVIEW}

This study focuses on millennial engineers working in IT sector in Turkey and aims to investigate the effect of authentic leadership on their intrinsic motivation on the basis of self-determination theory. Therefore, a literature review is carried out on three main concepts: millennial generation, authentic leadership and intrinsic motivation.

\section{Millennial Generation}

There are different generational cohorts in the workforce including Baby Boomers, Generation $X$ and Generation Y. These generations differ from each other in ways that are important for people who leads them (Macky et al., 2008). Tulgan (1996) states that different leadership styles will suit the employees with different work characteristics so that they will be more effective and productive (Yu et al, 2005).

More attention is being given to millennials as it is realized that their attitudes, beliefs and aspirations in the workplace are different from the previous generations (Chou, 2012). Millennial Generation is also known as Generation Y. Levine (2008) states that although there is no consensus in regards to age range of millennials, most scholars agree that individuals who were born between 1980 - 2000 are regarded as Generation $\mathrm{Y}$ (Mhatre \& Conger, 2011).

The first millennial graduated from college and entered the workforce in the summer of 2004. Every year new millennials are becoming a part of work life and this will continue until around 2022 (Hershatter \& Epstein, 2010). Balda \& Mora (2011) state that "we live in a complex world where we know little about leading and being led by millennials" (p. 13). Each generation view leadership in the perspective of their attitudes, values, and beliefs (Arsenault, 2004). This requires the leaders or managers to first understand the millennials' perception and expectation on what an effective leader is. Then the next step will be implementing the most appropriate leadership style that satisfies the needs and wants of millennial workforce.

A number of studies have been carried out on leading millennials. Balda \& Mora (2011) studied how service leadership can be effective in leading millennials in collaborative organizations. They considered millennials as "knowledge workers" (p. 13) and focused on their characteristics in building relationships, collaboration and knowledge creation. They revised servant leadership and proposed an alternative that fits the mental model of many millennials: service leadership. They defined service leadership as "relational leadership" (p. 22) that provides opportunities to gain from and develop with others, to be challenged by relevant work that matches the abilities of the individual and to share the work life in achieving targets (Balda \& Mora, 2011).

Rodriguez et al. (2015) studied millennials and cloud leadership. They saw leadership as a cloud and defined cloud leader as "a leader for the coming future" (p. 854). They focused on the leaders who face a volatile, uncertain, complex and ambiguous world (VUCA) and a generation that is bringing a new approach to relationships, work and information exchange. They evaluated whether cloud leadership can overcome the present reality of consistent change, redirection and new frontiers. They finally proposed that raising, building, exploiting the dynamism that every individual has is an advantage of a cloud leader in a VUCA world where millennials have a strong presence. Furthermore, a cloud leader who attempts to "bring out" the positive in each person and who looks for the opportunities that will improve their capabilities can have long lasting effects on millennial individuals.

Maier et al. (2015) studied millennial generation hospitality students and their perceptions of value-centered leadership principles. They proposed that it will be beneficial if leaders leading millennials consider the following recommendations: 1 ) forming team-based workgroups with a mentor that guides their work with 


\section{B. Aydoğdu - D. Palalar Alkan 11/3 (2019) 1503-1517}

a more laissez-faire leadership style 2) increasing flexibility in the workplace 3) empowering millennials and encouraging them to take their own decisions 4) emphasizing ethical principles and recognizing ethical practices.

\section{Authentic Leadership}

Leadership has always been very critical in challenging and turbulent times. In the early years of $21^{\text {st }}$ century, the difficulties that organizations face in these critical times resulted in a need for a renewed focus on a distinctive form of leadership. Authentic leadership gained a considerable recognition as the new and genuine form of leadership among scholars (Luthans \& Avolio, 2003; Seligman, 2002) and practitioners (George, 2003) (Avolio \& Gardner, 2005). The researchers who contributed authentic leadership concept to the literature state that existing leadership approaches are not sufficient to develop leaders who can deal with today's ethical (e.g., Enron) and societal (e.g., September 11 terrorism, fluctuating stock values) challenges and therefore a more positive leadership approach is crucial (Cooper et al., 2005).

The root of "authenticity" can be traced back to ancient Greek philosophy "to thine own self to be true" (Cameron et al., 2003: 242). In the positive psychology literature, authenticity is defined as "owning one's personal experiences and acting in accord with true self" (Cameron et al., 2003, p. 242). Cameron et al. (2003) suggests that that meaning of authenticity best portrays the type of positive leadership needed today "where the environment is dramatically changing, where the rules that have guided how we operate no longer work, and where the best leaders will be transparent with their intentions, having a seamless link between their espoused values, actions and behaviors" (p. 242).

Many scholars conducted studies about authentic leadership. In this study, Walumbwa et al.'s (2008) definition, given below, is utilized to depict four dimensions of authentic leadership: self-awareness, internalized moral perspective, balanced processing, relational transparency.

"We define authentic leadership as a pattern of leader behavior that draws upon and promotes both positive psychological capacities and a positive ethical climate, to foster greater self-awareness, an internalized moral perspective, balanced processing of information, and relational transparency on the part of leaders working with followers, fostering positive self-development." (Walumbwa et al., 2008, p. 94)

\section{Intrinsic Motivation and Self-Determination Theory}

Self-determination theory (SDT) is an approach to human motivation and personality in social contexts. The theory draws from the experiments conducted to investigate the effects of extrinsic rewards on intrinsic motivation.

One of the theories utilized to explain self-determination theory is Organismic Integrations Theory (OIT) which suggests that people are naturally willing to integrate their ongoing experiences if they have the necessary nutriments (Deci \& Ryan, 2002). Deci \& Ryan (2002) states that "the more fully a regulation (or the value underlying it) is internalized, the more it becomes part of the integrated self and the more it is the basis for self-determined behavior" (p. 15). According to OIT, intrinsic motivation is a result of selfdetermined behavior and intrinsically motivated individuals do the activity because it is interesting and they are inherently satisfied by doing it (Deci \& Ryan, 2002).

Dysvik \& Kuvaas (2010) states that there is a negative relationship between intrinsic motivation and turnover intention of employees. In other words, employees who are high in intrinsic motivation have a lower tendency to leave their jobs. This result is compatible with Richer et al.'s (2002) research which adds that "turnover intentions in the end translate into turnover behavior" (p. 2089). Furthermore, Thatcher et al. (2006) who studied the effect of intrinsic motivation on IT workers' behaviors and intentions proposes that intrinsic motivation positively influences job satisfaction while job satisfaction positively influences affective organizational commitment and both of these factors, job satisfaction and affective organizational commitment, have a negative influence on turnover intent.

There is a limited literature that investigates the relationship between authentic leadership and intrinsic motivation of millennial generation. As mentioned above, leaders and managers have difficulty in 


\section{B. Aydoğdu - D. Palalar Alkan 11/3 (2019) 1503-1517}

understanding, motivating millennials and sustaining the workforce in the long run. In this study, the relationship between authentic leadership and intrinsic motivation level of millennial engineers is studied. The main hypothesis developed is as the following:

$H_{1}$ : There is a relationship between authentic leadership and intrinsic motivation level of millennial engineers working in IT sector in Turkey.

In addition, to explore the effect of demographic variables (gender, age, education level, work experience and job tenure) on both authentic leadership and intrinsic motivation level of millennial engineers, two following research questions have been formulated:

Question 1: What is the relation between demographic variables (gender, age, education level, work experience and job tenure) and authentic leadership?

Question 2: What is the relation between demographic variables (gender, age, education level, work experience and job tenure) and intrinsic motivation?

\section{METHODOLOGY}

\section{Research Design and Model}

In this study the leadership style of millennial engineers' leaders and the reasons why millennial engineers do their work is examined in order to explore the relationship between authentic leadership and intrinsic motivation level of millennial engineers. The research model is shown in Figure 1. The dependent variable is the intrinsic motivation level of millennial engineers working in IT sector in Turkey and the independent variable is the authentic leadership style that is used by managers or leaders of millennial engineers.

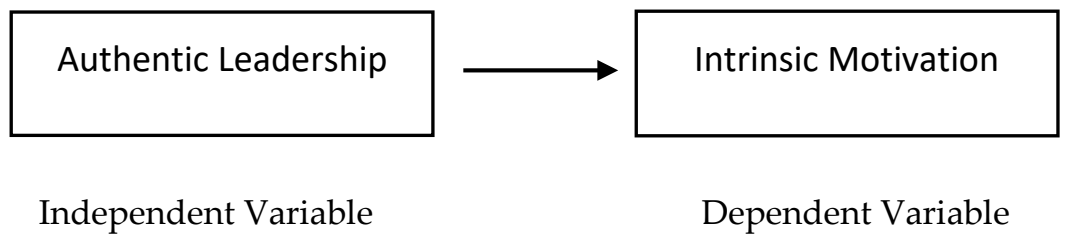

Figure1: Conceptual Model

\section{Measurement Instruments}

Survey technique is used to collect data from the respondents. Online survey is carried out with the engineers working for at least one year or more in IT departments of different companies operating in finance, telecommunication and software development sector in Turkey. The survey is prepared with Survey Monkey and sent to the participants via e-mail and Linked-in posts.

The survey is composed of three sections:

- The 1st section is to get demographic information of millennial engineers. This section is composed of 5 multiple choice questions about gender, age, education level, work experience and job tenure.

- The 2nd section is to assess authentic leadership of the leaders of millennial engineers. Authentic Leadership Questionnaire (ALQ) is used with a five-point Likert-type scale where 1= "Not at all" to $5=$ "Frequently, if not always".

ALQ is a measure of authentic leadership based on four components:

1. self-awareness refers to "demonstrating an understanding of how one derives and makes meaning of the world and how that meaning making process impacts the way one views himself or herself over time"

2. relational transparency refers to "presenting one's authentic self to others"

3. balanced processing refers to "leaders who show that they objectively analyze all relevant data before coming to a decision" 


\section{B. Aydoğdu - D. Palalar Alkan 11/3 (2019) 1503-1517}

4. internalized moral perspective refers "to an internalized and integrated form of selfregulation" (Walumbwa et al. 2008).

This section has 16 questions. The participants are asked to evaluate their immediate supervisors.

Permission for scientific use of the ALQ is obtained from Mind Garden Institute.

- The 3rd section is to assess intrinsic motivation of millennial engineers. Work Extrinsic and Intrinsic Motivation Scale (WEIMS) is used with a five-point Likert-type scale where $1=$ "Does not correspond at all" to $5=$ "Corresponds exactly". WEIMS is a measure of work motivation theoretically grounded in self-determination theory (Tremblay et al., 2009).

This section has 18 questions. The participants are asked to evaluate their immediate supervisors.

All the questions in the survey are required to answer.

\section{Research Sample}

Convenience sampling method (non-probability sampling) is used. The survey is sent to the people working as an engineer in IT departments of banks (ING Bank, Garanti Bank, Ziraat Bank, Akbank, IBTech, Yap1 Kredi Bank), telecommunication (Turkcell, Netaş) and software development (Sony Eurasia) companies located in İstanbul. The sample includes both male and female engineers at different ages (born between 1982 - 1996) belonging to millennial generation. The data is collected at a single point in time (between 13.02.2018 and 01.04.2018), hence the data is cross-sectional.

The research population consists of the millennial engineers working in IT sector in Turkey. The sample size is $196.68 .4 \%$ of the respondents is male and $31.6 \%$ is female. $26 \%$ of the respondents are between 22 and 26 years old, $34.7 \%$ are between 27 and 31 years old while $39.3 \%$ are between 32 and 36 years old. In terms of education level, most of the respondents have bachelor's degree (78\%). $10.7 \%$ of the respondents have a work experience less than 1 year and while others' work experience varies between 1 to 15 years. 32.7\% of the respondents have a job tenure less than 1 year and $3 \%$ have a job tenure of more than 10 years. Table 1 presents the respondents' characteristics in detail.

Table 1. Demographic Statistics of The Respondents

\begin{tabular}{llll} 
Variable & Groups & $\mathbf{N}$ & Percentage(\%) \\
\hline Gender & Male & 134 & 68.4 \\
& Female & 62 & 31.6 \\
Total & $22-26$ & 196 & 100 \\
\hline Age & $27-31$ & 51 & 26 \\
& $32-36$ & 68 & 34.7 \\
& Total & 77 & 39.3 \\
& Associate degree & 196 & 100 \\
\hline Education Level & Bachelor's degree & 2 & 1 \\
& Master's degree & 153 & 78 \\
& Doctor's degree & 39 & 20 \\
& Total & 2 & 1 \\
& $<1$ & 196 & 100 \\
\hline Work Experience & $1-5$ & 21 & 10.7 \\
& $6-10$ & 62 & 31.6 \\
& $11-15$ & 62 & 31.6 \\
& Total & 51 & 26 \\
& $<1$ & 196 & 100 \\
\hline Job Tenure & $1-3$ & 64 & 32.7 \\
& $4-5$ & 61 & 31.1 \\
& $6-7$ & 35 & 17.8 \\
& $8-10$ & 22 & 11.2 \\
& $10+$ & 8 & 4.1 \\
& Total & 6 & 3.1 \\
& & 196 & 100 \\
\hline
\end{tabular}




\section{RESULTS}

Statistical analyses were performed in several steps. First of all, to determine the main factors of Authentic Leadership scale and Work Extrinsic and Intrinsic Motivation Scale factor analysis was conducted. Principal Component Analysis with Varimax Rotation was used for factor analysis. Then, reliability was tested by using Cronbach's alpha. Independent-Samples T-Test, One-Way ANOVA and Kruskal Wallis were applied to find out if there were any differences between different demographic groups in terms of authentic leadership and intrinsic motivation. Then, Pearson's Product Moment Correlation was calculated to demonstrate the correlations between the variables. Finally, in order to see the relationship between authentic leadership and intrinsic motivation, linear regression analysis was used.

\section{Factor and Reliability Analysis Results of Authentic Leadership Scale}

Factor analysis was conducted for 16 items of Authentic Leadership Questionnaire listed in Table 2 and Principal Component Analysis with Varimax Rotation was used to determine the main factors of Authentic Leadership variable.

Table 2. Items of Authentic Leadership Scale

Relational Transparency

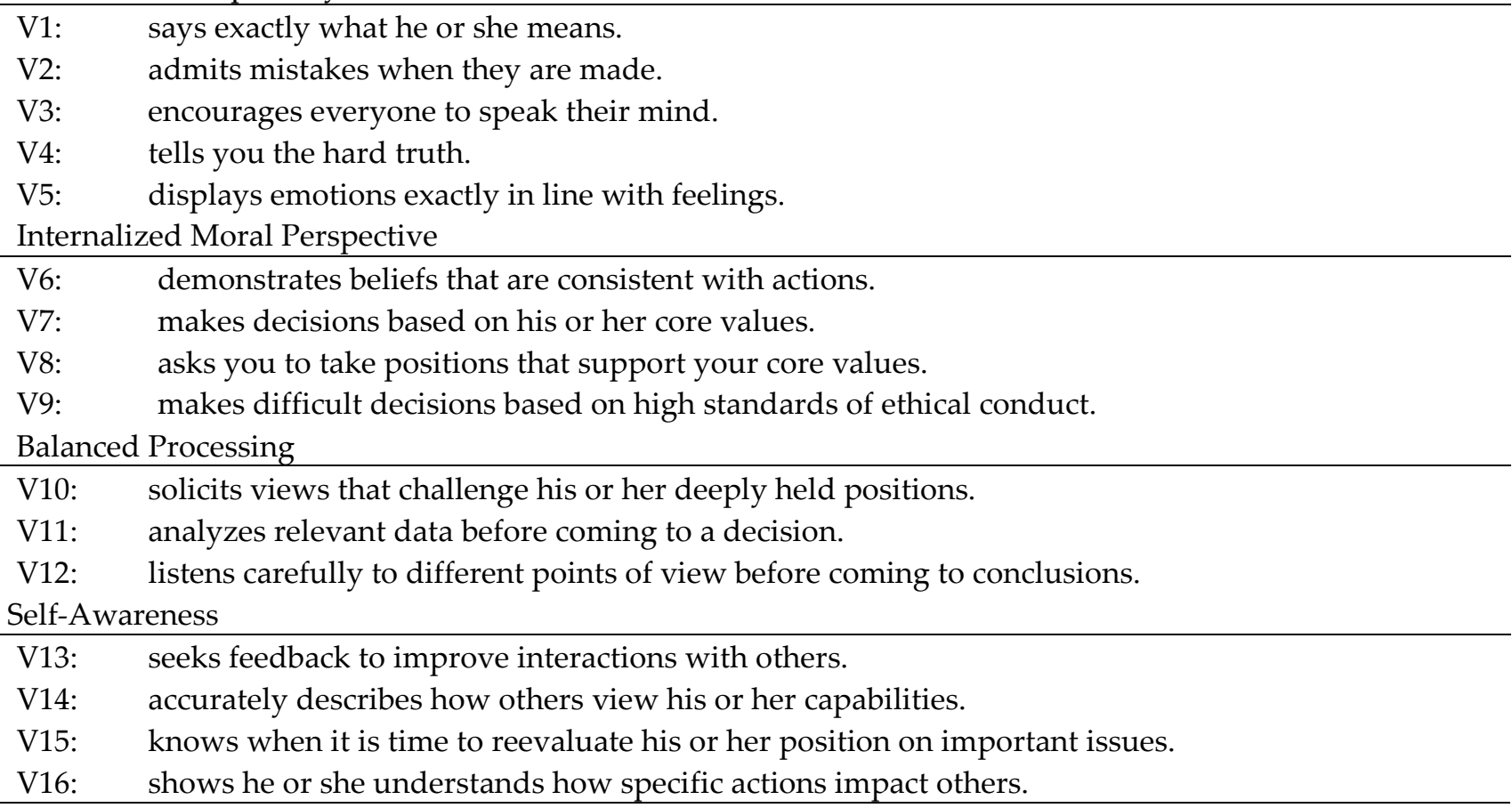

Kaiser-Meyer-Olkin (KMO) measure of sampling adequacy and Bartlett's test of sphericity were used to check if data were convenient for factor analysis. The KMO value which was calculated as 0,937 and the results of Bartlett's test of sphericity (Sig.: .000, Approx. Chi-Square: 1670.398, df: .120) showed that the data were suitable for factor analysis.

Item 1, Item 4 and Item 6 has been excluded because they had close factor loadings (V1: .539 under Factor 1, .461 under Factor 2; V4: .436 under Factor 1, .570 under Factor 2; V6: .510 under Factor 1, .643 under Factor 2). Confirmatory factor analysis was done after the exclusion of these items. The KMO value was calculated as 0,926 and the Bartlett's test of sphericity results were Approx. Chi-Square: 1294.958, df: 78, Sig.: .000. The remaining 13 items were loaded on two factors, as can be seen in Table 3, explaining $59.482 \%$ of the total variance. 
Table 3. Factor Analysis Results of Authentic Leadership Scale

\begin{tabular}{|c|c|c|}
\hline Factor 1: & \% Variance: 46.067 & Factor Loadings \\
\hline V15 & $\begin{array}{l}\text { knows when it is time to reevaluate his or her position on } \\
\text { important issues. }\end{array}$ & .821 \\
\hline V12 & $\begin{array}{l}\text { listens carefully to different points of view before coming to } \\
\text { conclusions. }\end{array}$ & .812 \\
\hline V13 & seeks feedback to improve interactions with others. & .794 \\
\hline V16 & shows he or she understands how specific actions impact others. & .789 \\
\hline V14 & accurately describes how others view his or her capabilities. & .734 \\
\hline V3 & encourages everyone to speak their mind. & .730 \\
\hline V10 & solicits views that challenge his or her deeply held positions. & .721 \\
\hline V8 & asks you to take positions that support your core values. & .701 \\
\hline V2 & admits mistakes when they are made. & .651 \\
\hline V11 & analyzes relevant data before coming to a decision. & .645 \\
\hline V9 & $\begin{array}{l}\text { makes difficult decisions based on high standards of ethical } \\
\text { conduct. }\end{array}$ & .637 \\
\hline Factor 2: & \% Variance: 13.415 & Factor Loadings \\
\hline V5 & displays emotions exactly in line with feelings. & .860 \\
\hline V7 & makes decisions based on his or her core values. & .745 \\
\hline
\end{tabular}

Kaiser-Meyer-Olkin Measure of Sampling Adequacy: .926

Bartlett's Test of Sphericity: Approx. Chi-Square: 1294.958, df: 78, Sig.: .000

After Factor Analysis, Reliability Analysis was performed for each of the factors of Authentic Leadership scale. Cronbach's alpha score was .924 for Factor 1 indicating that this factor was highly reliable (above the generally accepted score of .70.) whereas Cronbach's alpha score was .558 for Factor 2 indicating that this factor was unreliable (below the generally accepted score of .70). Therefore, Factor 2 was excluded in the following analyses.

As mentioned in the literature review section, authentic leadership has four dimensions: self-awareness, internalized moral perspective, balanced processing, relational transparency (Walumbwa et al. 2008). However, in this study 11 items of authentic leadership were loaded into one factor including 4 items from Self- Awareness, 3 items from Balanced Processing, 2 items from Relational Transparency and 2 items from Internalized Moral Perspective dimensions. Thus, this factor has been named as "Authentic Leadership".

\section{Factor and Reliability Analysis Results of Work Extrinsic and Intrinsic Motivation Scale}

Factor analysis was conducted for 3 items of Work Extrinsic and Intrinsic Motivation Scale which were designed to measure intrinsic motivation. These items are listed in Table 4. Principal Component Analysis with Varimax Rotation was used to determine the main factors of intrinsic motivation variable.

Table 4. Items of Work Extrinsic and Intrinsic Motivation Scale

Intrinsic Motivation

V1: $\quad$ Because I derive much pleasure from learning new things.

V2: $\quad$ For the satisfaction I experience from taking on interesting challenges.

V3: For the satisfaction I experience when I am successful at doing difficult tasks.

Kaiser-Meyer-Olkin (KMO) measure of sampling adequacy and Bartlett's test of sphericity were used to check if data were convenient for factor analysis. The KMO value which was calculated as .716 and the results of Bartlett's test of sphericity (Sig.: .000, Approx. Chi-Square: 207.636, df: .3) showed that the data were suitable for factor analysis.

Factor analysis results indicated that there was only one factor. This factor was named as "Intrinsic 


\section{B. Aydoğdu - D. Palalar Alkan 11/3 (2019) 1503-1517}

Motivation". Afterwards, Reliability Analysis was performed and Cronbach's alpha score was calculated as .821 indicating that the factor was reliable (above the generally accepted score of .70).

\section{Results of T-Test, ANOVA and Kruskal Wallis}

Before testing the hypothesis, the research questions regarding the relation of demographic variables (gender, age, education level, work experience and job tenure) with both authentic leadership and intrinsic motivation were tested.

On the first step, Independent-Samples T-Test was applied to analyze whether there were differences between males and females with respect to the level of authentic leadership and intrinsic motivation. No significant difference was found between the two groups in terms of authentic leadership (Sig. $=.934)$ and intrinsic motivation (Sig. $=.200)$.

On the second step, One-Way ANOVA was applied to analyze whether there were differences between different age groups with respect to the level of authentic leadership and intrinsic motivation. It was found that there wasn't a significant difference between different age groups in terms of authentic leadership (Sig. $=.101)$ and intrinsic motivation (Sig. $=.059$ ).

On the third step, Kruskal Wallis Test was applied to test the differences in different education levels with respect to the level of authentic leadership and intrinsic motivation. One-Way ANOVA couldn't be used because the sample size of two groups (Associate degree and Doctor's degree) was less than 30 . The results of the analysis showed that there wasn't a significant difference between different education levels in terms of authentic leadership (Asymp. Sig. $=.971$ ) and intrinsic motivation (Asymp. Sig. $=.408$ ).

On the fourth step, Kruskal Wallis Test was applied to analyze whether there were differences between different work experiences with respect to the level of authentic leadership and intrinsic motivation. OneWay ANOVA couldn't be used because the sample size of one group (work experience less than 1 year) was less than 30. It was found that there wasn't a significant difference between different work experiences in terms of intrinsic motivation (Asymp. Sig. $=.162$ ). However, there was a significant difference between different work experiences in terms of authentic leadership (Asymp. Sig. $=.013$ ). Post hoc tests were conducted to test pairwise comparisons. Pairwise comparisons (with Bonferroni correction) revealed that there was a significant difference (Adj. Sig. =.007) between work experiences of "11-15 years" and "<1 year". Participants with the least work experience view their leaders more authentic than the ones with the most work experience.

On the fifth step, Kruskal Wallis Test was applied to test the differences between different job tenures with respect to the level of authentic leadership and intrinsic motivation. One-Way ANOVA couldn't be used because the sample size of three groups ( $6-7$ years, $8-10$ years, $10+$ years) was less than 30 . The results of the analysis showed that there was a significant difference between different job tenures in terms of authentic leadership (Asymp. Sig. $=.035$ ) and intrinsic motivation (Asymp. Sig. $=.029$ ). For both of the variables, post hoc tests were conducted in order to find which groups were statistically different from each other. Regarding intrinsic motivation, pairwise comparisons (with Bonferroni correction) showed that there was a significant difference (Adj. Sig. $=.013$ ) between job tenures of " $4-5$ years" and " $<1$ year". Millennial engineers with a job tenure of less than 1 year were found to be more intrinsically motivated that the ones with job tenures of " $4-5$ years". Regarding authentic leadership variable, multiple post hoc tests were conducted but results showed that none of the pairwise tests were significant.

\section{Results of Correlation, Regression Analysis and Hypothesis Test}

In order to see the contribution of authentic leadership on intrinsic motivation, correlation and regression analysis were conducted. First of all, normality tests were conducted to assess the normality of the data collected. According to George \& Mallery (2016) a kurtosis and skewness value between -2.0 and 2.0 is acceptable for normality. As can be seen in Table 5, the kurtosis and skewness values were in this range, so the data was accepted as normally distributed. 
B. Aydoğdu - D. Palalar Alkan 11/3 (2019) 1503-1517

Table 5. Normality Test Results of Authentic Leadership and Intrinsic Motivation

\begin{tabular}{llll} 
Variable & & Statistic & Std. Error \\
\hline Authentic Leadership & Skewness & -.552 & .174 \\
& Kurtosis & .128 & .346 \\
\hline Intrinsic Motivation & Skewness & -.700 & .174 \\
& Kurtosis & .358 & .346 \\
\hline
\end{tabular}

On the second step, Pearson's product-moment correlation was conducted. The results, as shown in Table 6, indicated that there was a moderate, positive relation between authentic leadership and intrinsic motivation $(\mathrm{r}=.314 ; p=.000)$.

Table 6. Pearson's Product-Moment Correlation Results

Variables

\begin{tabular}{ll|l}
\hline Authentic Leadership, & Pearson Correlation $(\mathrm{r})$ & $.314^{* *}$ \\
\cline { 2 - 3 } \begin{tabular}{l} 
Intrinsic Motivation \\
\cline { 2 - 3 }
\end{tabular} & .000 \\
\cline { 2 - 3 } & $\mathrm{N}$ & 196 \\
\hline
\end{tabular}

**. Correlation is significant at the 0.01 level (2-tailed).

On the third step, linear regression analysis was conducted. Authentic Leadership was put into regression as the independent variable and Intrinsic Motivation was put into as the dependent variable. The results indicated that Authentic Leadership had a contribution on Intrinsic Motivation $(\beta=.367 ; p$ value $=.000)$ as seen in Table 7. So, Hypothesis 1 is accepted.

Table 7. Linear Regression Analysis Results

\begin{tabular}{llll} 
Independent Variable & $\beta$ & $t$ & $p$ \\
\hline Authentic Leadership & .367 & 4.613 & .000 \\
\hline $\mathbf{R}=.314 ; \mathbf{R}^{2}=.099 ; \mathbf{F}$ value= 21.282; $\mathbf{p}$ value= .000 & \\
Dependent Variable: Intrinsic & Motivation & &
\end{tabular}

\section{DISCUSSION}

The primary purpose of this study was to investigate the contribution of authentic leadership on intrinsic motivation of millennial engineers working in Information Technology sector in Turkey. As given in the conceptual model, the dependent variable of this study was intrinsic motivation and the independent one was authentic leadership. In addition to the hypothesis developed, the effect of demographic variables on dependent and independent variables were questioned.

As mentioned in the literature review section, Walumbwa et al. (2008) states that authentic leadership has four dimensions which are self-awareness, internalized moral perspective, balanced processing and relational transparency. However, in this study factor analysis of Authentic Leadership scale revealed that authentic leadership had only one-dimension since 11 items of Authentic Leadership scale were loaded into one factor. Although this result was not consistent with the study of Walumbwa et al. (2008), it was compatible with Erkutlu et al.'s (2013) study about the effects of trust and psychological contract violation on authentic leadership and organizational deviance. They used ALQ with a five-point Likert-type scale and the principal component analysis of ALQ revealed only one factor with an eigenvalue greater than 1.0. Their research sample included people living in Turkey as in the case of this study. Furthermore, factor analysis of Work Extrinsic and Intrinsic Motivation Scale, conducted with the items designed to measure intrinsic motivation, yielded one factor which was compatible with the study of Tremblay et al. (2009).

Results of correlation analysis showed that there was a moderate, positive relation between authentic leadership and intrinsic motivation of millennial engineers and regression analysis results indicated that authentic leadership had a contribution on intrinsic motivation. This means that authentic leadership 


\section{B. Aydoğdu - D. Palalar Alkan 11/3 (2019) 1503-1517}

increases intrinsic motivation of millennial engineers. Moreover, millennial engineers working with authentic leaders show more self-determined behaviors and involve more in activities that they are inherently satisfied by doing. This result has important implications for the organizations that have millennial engineers.

Furthermore, tests that were carried out to explore the effect of demographic variables (gender, age, education level, work experience and job tenure) on both authentic leadership and intrinsic motivation level of millennial engineers, showed that there was no significant difference between different genders, different age groups and different education levels in terms of authentic leadership and intrinsic motivation.

Regarding work experience, it was found that there wasn't a significant difference between different work experiences in terms of intrinsic motivation. However, there was a significant difference between different work experiences in terms of authentic leadership. Pairwise comparisons revealed that millennial engineers with the least work experience viewed their leaders more authentic than the ones with the most work experience. This is not a desired outcome for leaders since they prefer an increase or stability rather than a decrease in the perception of authenticity.

For the last demographic variable which was job tenure, the results of the analysis showed that there was a significant difference between different job tenures in terms of authentic leadership and intrinsic motivation. Millennial engineers with a job tenure of less than 1 year was found to be more intrinsically motivated that the ones with job tenures of " $4-5$ years". This result is compatible with Moynihan et al.'s (2007) study which proposes that job tenure has a negative relationship with job involvement and job involvement is an important aspect of work motivation. Regarding authentic leadership although multiple post hoc tests were conducted, results didn't reveal which groups were statistically different from each other.

\section{LIMITATIONS OF THE STUDY}

The most important limitation of this study is the sample size. There were 196 participants from IT departments of six banks (ING Bank, Garanti Bank, Ziraat Bank, Akbank, IBTech, Yapı Kredi Bank), two telecommunication companies (Turkcell, Netaş) and one software development (Sony Eurasia) company. The participation to the study was voluntary and convenient sampling method was used. In addition to the number of participants, the number of leaders being evaluated were limited. Besides, the majority of the participants and leaders were working in the same sector, banking sector. And the target population was living in Istanbul which has a working climate of its own. All these restrictions made it difficult to generalize the findings.

Another limitation of this study is the time frame which was relatively short between February 2018 and April 2018. Hence, the study was cross-sectional and the data were collected at a single point in time. Therefore, the findings may not be applicable to other time frames.

One other limitation of this study is the participants who didn't evaluate their leaders honestly and objectively. Furthermore, the participants' evaluation was affected by factors such as organizational culture, working environment, employee satisfaction, organization's investment in innovation and personal characteristics.

More generalizable findings might be obtained if this study is carried out by a larger number of participants working in IT departments of companies operating in different sectors and if the data are collected within a longer time frame.

\section{MANAGERIAL IMPLICATIONS}

This study shows that there is positive relationship between authentic leadership and intrinsic motivation of millennial engineers working in IT sector in Turkey. This outcome can provide valuable insights to both organizations and leaders.

Organizations with millennial employees more or less know what "intrinsic motivation" is and are aware of its importance. That's why they try to measure how motivated their employees are and carry out programs to increase or keep the existing motivation level. However, authentic leadership is a relatively new concept for them. 


\section{B. Aydoğdu - D. Palalar Alkan 11/3 (2019) 1503-1517}

Most of the organizations provide a series of trainings to develop new leaders within the organization. In the light of this study, they should prepare training programs about what authentic leadership is, how to be an authentic leader and what authenticity brings. The difference of intrinsic motivation from extrinsic one and its value to organization should also be strongly emphasized. In addition to this, a program for the existing leaders of the organization should be designed and carried out. This program should support transition from the already practiced leadership style to authentic leadership and bring all the leaders to the same awareness and knowledge level about authenticity. Eventually, when the leaders become more authentic, employees working with these leaders will get more intrinsically motivated. And with its authentic leaders and intrinsically motivated employees, the organization will be more successful in sustaining its workforce in the long run and competing against its rivals.

In addition to the training programs, the result of this study can give insights about recruitment processes. As widely known, Human Resources Management departments try to select the candidates best fit the organization culture and job definition. Given the result of this study, Human Resources Departments should add "authenticity" criterion for evaluation of candidates for leadership positions. Thus, it will take less time for the organization to develop the recruited leaders as authentic leaders.

Regarding the relation between authentic leadership and work experience, leaders should first understand the root cause of why millennials' perception of authenticity decreases as work experience increases and then formulate solutions that will change their perceptions positively as they get more experienced. Similarly, leaders of the organization should analyze why millennials with more job tenures are less intrinsically motivated than the ones with less job tenures. Surveys can be helpful to discover the reasons that brings this result. Based on the analysis, leaders should find ways to keep or increase intrinsic motivation of millennials as their job tenure increases.

Furthermore, the result of this study may provide organizations and leaders different viewpoints when creating short-term and long-term strategies, policies, organizational goals. Moreover, leaders may try different ways of working on the basis of authentic leadership principles.

As given in the previous sections, this study was carried out in Turkey and surveys were filled out by the millennial engineers working in IT departments of different companies. For future research, this research can be widened to millennial white-collar employees working in different departments of companies operating in different sectors in Turkey and to explore the effect of national culture on the relationship between authentic leadership and intrinsic motivation surveys can be conducted in other countries.

\section{REFERENCES}

Arsenault, P. M. (2004). Validating generational differences: A legitimate diversity and leadership issue. Leadership \& Organization Development Journal, 25(2), 124-141.

Avolio, B. J., \& Gardner, W. L. (2005). Authentic leadership development: Getting to the root of positive forms of leadership. The leadership quarterly, 16(3), 315-338.

Balda, J. B., \& Mora, F. (2011). Adapting leadership theory and practice for the networked, millennial generation. Journal of Leadership Studies, 5(3), 13-24.

Bharadwaj, A. S. (2000). A resource-based perspective on information technology capability and firm performance: an empirical investigation. MIS quarterly, 169-196.

Cameron, K., \& Dutton, J. (Eds.). (2003). Positive organizational scholarship: Foundations of a new discipline. Berrett-Koehler Publishers.

Chou, S. Y. (2012). Millennials in the workplace: A conceptual analysis of millennials' leadership and followership styles. International Journal of Human Resource Studies, 2(2), 71.

Cooper, C. D., Scandura, T. A., \& Schriesheim, C. A. (2005). Looking forward but learning from our past: Potential challenges to developing authentic leadership theory and authentic leaders. The Leadership Quarterly, 16(3), 475-493.

Deci, E. L., \& Ryan, R. M. (Eds.). (2002). Handbook of self-determination research. University Rochester Press. 


\section{B. Aydoğdu - D. Palalar Alkan 11/3 (2019) 1503-1517}

Dysvik, A., \& Kuvaas, B. (2010). Exploring the relative and combined influence of mastery-approach goals and work intrinsic motivation on employee turnover intention. Personnel review, 39(5), 622-638.

Erkutlu, H., \& Chafra, J. (2013). Effects of trust and psychological contract violation on authentic leadership and organizational deviance. Management Research Review, 36(9), 828-848.

Gardner, W. L., Cogliser, C. C., Davis, K. M., \& Dickens, M. P. (2011). Authentic leadership: A review of the literature and research agenda. The Leadership Quarterly, 22(6), 1120-1145.

George, W. (2003). Authentic leadership: Rediscovering the secrets to creating lasting value. San Francisco7 JosseyBass

George, D., \& Mallery, P. (2016). IBM SPSS statistics 23 step by step: A simple guide and reference. Routledge.

Glass, A. (2007). Understanding generational differences for competitive success. Industrial and commercial training, 39(2), 98-103.

Hershatter, A., \& Epstein, M. (2010). Millennials and the world of work: An organization and management perspective. Journal of Business and Psychology, 25(2), 211-223.

Levine, S. (2008, April 28). Commentary: Levine on leadership. Long Island Business News, p. 1.

Luthans, F., \& Avolio, B. J. (2003). Authentic leadership: A positive developmental approach. In K. S. Cameron, J. E. Dutton, \& R. E. Quinn (Eds.), Positive organizational scholarship (pp. 241 - 261). San Francisco7 Barrett-Koehler.

Macky, K., Gardner, D., \& Forsyth, S. (2008). Generational differences at work: Introduction and overview. Journal of Managerial Psychology, 23(8), 857-861.

Maier, T., Tavanti, M., Bombard, P., Gentile, M., \& Bradford, B. (2015). Millennial generation perceptions of value-centered leadership principles. Journal of Human Resources in Hospitality \& Tourism, 14(4), 382397.

Mhatre, K. H., \& Conger, J. A. (2011). Bridging the gap between Gen X and Gen Y. Journal of Leadership Studies, 5(3), 72-76.

Moynihan, D. P., \& Pandey, S. K. (2007). Finding workable levers over work motivation: Comparing job satisfaction, job involvement, and organizational commitment. Administration \& Society, 39(7), 803832.

Richer, S. F., Blanchard, C., \& Vallerand, R. J. (2002). A motivational model of work turnover. Journal of Applied Social Psychology, 32(10), 2089-2113.

Rodriguez, A., \& Rodriguez, Y. (2015). Metaphors for today's leadership: VUCA world, millennial and "Cloud Leaders". Journal of Management Development, 34(7), 854-866.

Seligman, M. E. P. (2002). Authentic happiness: Using the new positive psychology to realize your potential for lasting fulfillment. New York7 Free Press.

Sujansky, J., \& Ferri-Reed, J. (2009). Keeping the Millennials: Why companies are losing billions in turnover to this generation-and what to do about it. John Wiley \& Sons.

Thatcher, J. B., Liu, Y., Stepina, L. P., Goodman, J. M., \& Treadway, D. C. (2006). IT worker turnover: An empirical examination of intrinsic motivation. ACM SIGMIS Database: the DATABASE for Advances in Information Systems, 37(2-3), 133-146.

Tremblay, M. A., Blanchard, C. M., Taylor, S., Pelletier, L. G., \& Villeneuve, M. (2009). Work Extrinsic and Intrinsic Motivation Scale: Its value for organizational psychology research. Canadian Journal of Behavioural Science/Revue canadienne des sciences du comportement, 41(4), 213.

Tulgan, B. (1996), Managing Generation X: how to bring out the best in young talent, Capstone Publishing Limited, Oxford.

Tulgan, B. (2011). Generation Y. Journal of Leadership Studies, 5(3), 77-81.

Walumbwa, F. O., Avolio, B. J., Gardner, W. L., Wernsing, T. S., \& Peterson, S. J. (2008). Authentic leadership: Development and validation of a theory-based measure. Journal of management, 34(1), 89126.

Yu, H. C., \& Miller, P. (2005). Leadership style: The X Generation and Baby Boomers compared in different cultural contexts. Leadership \& Organization Development Journal, 26(1), 35-50. 


\section{B. Aydoğdu - D. Palalar Alkan 11/3 (2019) 1503-1517}

\section{APPENDIX}

\section{Online Survey}

$1^{\text {st }}$ Part

*1. What is your gender?

o Female

o Male

*2. What is your age?
o 22 to 26
o 27 to 31
o 32 to 36
o $36+$

*3. What is the highest degree or level of school you have completed?
o Associate degree
o Bachelor's degree
o Master's degree
o Doctor's degree

*4. What is your total work experience in this sector?
$0 \quad<1$
o $1-5$
o $6-10$
o 11-15

*5. How long have you been in your current company?
$\begin{array}{ll}0 & <1\end{array}$
o 1 - 3
o 4-5
o $6-7$
o $8-10$
o $10+$ 
2nd Part: Your Leader's Style

The following survey items refer to your leader's style, as you perceive it. Judge how frequently each statement fits his or her leadership style.

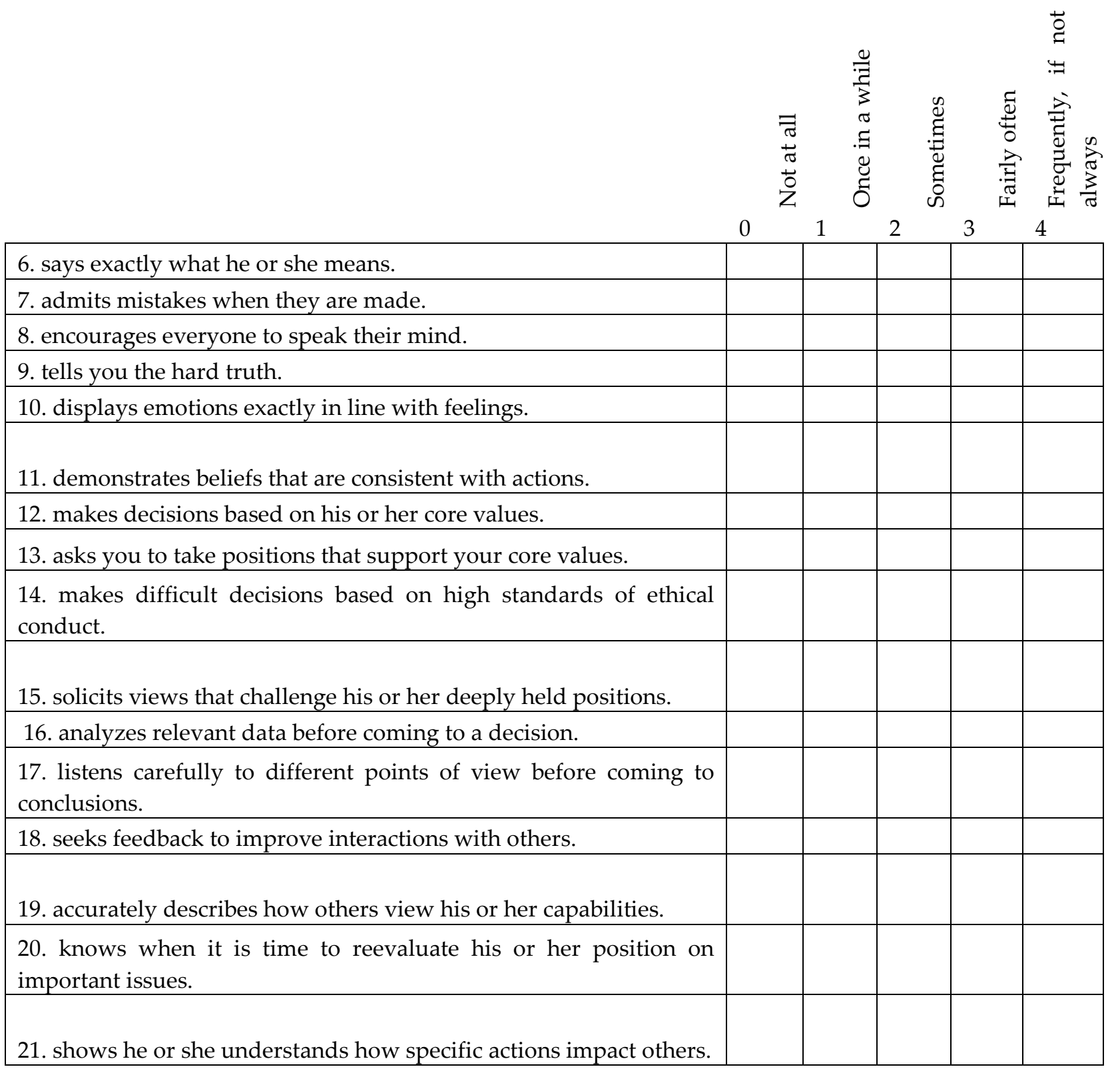




\section{B. Aydoğdu - D. Palalar Alkan 11/3 (2019) 1503-1517}

$3^{\text {rd }}$ Part: Why Do You Do Your Work?

Please indicate to what extent each of the following items corresponds to the reasons why you are presently involved in your work.

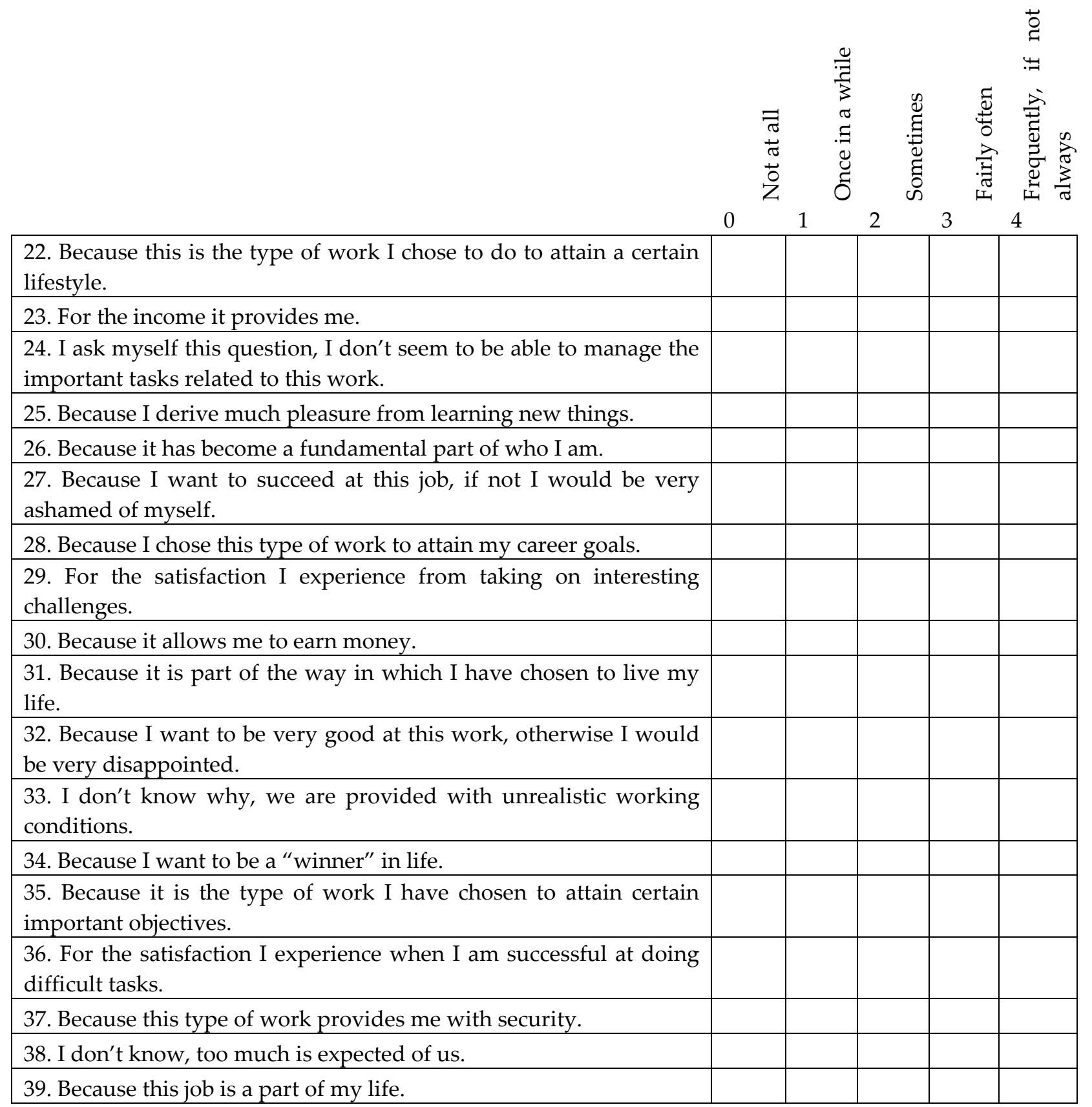

